Pesq. Vet. Bras. 35(8):741-748, agosto 2015 DOI: $10.1590 /$ S0100-736X2015000800006

\title{
Histochemical study of the oviducal gland and analysis of the sperm storage tubules of Mustelus schmitti Springer, 1939 (Chondrichthyes, Triakidae) ${ }^{1}$
}

\author{
Fernanda Gabriela Elías ${ }^{2}$
}

\begin{abstract}
Elías F.G. 2015. Histochemical study of the oviducal gland and analysis of the sperm storage tubules of Mustelus schmitti Springer, 1939 (Chondrichthyes, Triakidae). Pesquisa Veterinária Brasileira 35(8):741-748. Departamento de Biología, Bioquímica y Farmacia, Universidad Nacional del Sur, San Juan 670, Bahía Blanca, Buenos Aires, Argentina.E-mail: ferelias@criba.edu.ar

The paired oviducal glands of immature and mature females of Mustelus schmitti were examined macro and microscopically. Findings indicate that these glands possessed the same zonation as in most chondrichthyans from anterior to posterior: club, papillary, baffle and terminal zones. The whole gland is composed by simple tubular glands that connect with transverse grooves all along the organ. The club zone presents a typical indian club shape with a simple columnar and ciliated epithelium including secretory cells PAS (+) and $\mathrm{AB}(+)$. The papillary zone is characterized by lamella forming small and long cones in numbers of three. The epithelium of this zone contains ciliated cells with apical nuclei and secretory cells with basal nuclei that stain $\mathrm{AB}(+)$ The baffle zone consists of apically flattened lamellae alternating with spinnerets which are small projections disposed by both sides of the plateau. This whole structure is present in number of 8 or 9 units. A simple columnar ciliated epithelium covers the plateau and spinnerets and no AB or PAS staining is observed. The epithelium of the terminal zone is PAS (-) and AB (+), and elongated tubules, that run adjacent to the baffle zone are the site where groups of spermatozoa are clearly observed in the lumen. The epithelium of the sperm storage tubules do not stain with any of the dyes tested. Sperm was also observed in the baffle zone, presumably in its way to the fecundation in the oviduct because it displays no aggregation pattern and was between the folds of the epithelium. By scanning electron microscopy sperm was observed in the club and baffle zones in a gland which belonged to a pregnant female.
\end{abstract}

INDEX TERMS: Oviductal gland, sperm storage, histochemistry, Mustelus schmitti, Chondrichthyes.

\section{INTRODUCTION}

All chondrichthyan species develop a unique gland derived from the oviducts named oviducal gland (OG) according to the conventional terminology adopted by Hamlett et al. (1998a).

This gland is an expansion of the anterior oviduct when it is immature. Once it is mature acquires the typical heart's shape with lateral extensions that resemble ram's horns. It shows the four typical zones going from proximal to distal:

\footnotetext{
${ }^{1}$ Received on February 7, 2015.

Accepted for publication on July 8, 2015.

${ }^{2}$ Departamento de Biología, Bioquímica y Farmacia, Universidad Nacional del Sur, San Juan 670, Bahía Blanca, Buenos Aires, Argentina. E-mail: ferelias@criba.edu.ar
}

club, papillary, baffle and terminal (Hamlett et al. 1998a). The external and internal morphology of this gland have been studied by many authors (Metten 1939, Nalini 1940, Prasad 1945, 1948, Brown 1955, Rusaoüen et al. 1976, Hamlett 1996, 2002, Knight et al. 1996, Conrath \& Musick 2002, Hamlett et al. 1998, 2002, 2005, Smith et al. 2004, Storrie et al. 2008, Serra-Pereira et al. 2011).

In some species, the baffle zone is not developed, like in Urobatis halleri (Babel 1967), Urobatis jamaicensis (Hamlett 1996, Hamlett et al. 1998), Myliobatis nieuhofii (Prasad 1951). They present simple club and papillary zones.

Exceptionally, there is only one family, Narcinidae (Torpediniformes), which it has been reported to have no oviducal gland at all (Prasad 1945).

The club and papillary zones produce the different jelly 
coats that cover the egg in its way down to the uterus. The baffle zone secretes the various types of investments that also cover the egg. The terminal zone is where the sperm is stored and is the responsible for the formation of hair filaments on the surface of the capsule in some species of Raja.

According to Hamlett et al. (1998), despite the variations among species, the oviducal gland seems to use the same basic assembly process to produce tough or flexible egg capsules, candles or egg envelopes. The extrusion of the material is released through the grooves of the gland, forming a single lamella of the egg covering. The coat extruded in this way, arranges the molecules in a precisely and complexly disposition. This process has been investigated in oviparous species (Knupp et al. 1996, Knupp et al. 1998, Knupp \& Squire 1998, Koob \& Cox 1988, Rusaoüen et al. 1976, Smith et al. 2004, Oddone et al. 2008) but in none viviparous one; so it is assumed that in viviparous species occur the same.

\section{MATERIALS AND METHODS}

Specimens of Mustelus schmitti were collected from the Bahia Blanca estuary, each month, from 2002 to 2006. They were caught by longlines baited with shrimp (Caridea, Crustacea). The fishing was made at the top of the tide during the day.

A total of 24 animals were collected and processed; 11 were immature, ranging their length from $28,5 \mathrm{~cm}$ to $50 \mathrm{~cm}$. Six animals were maturing with a total length of $50-61 \mathrm{~cm}$ and 7 mature females with $61-69 \mathrm{~cm}$ in long; 4 of this last group were pregnant. Immature animals were those with small white or no visible previtellogenic follicles, the oviducal glands were small and undeveloped and the uteri were narrow along their lengths. Maturing animals were those in which the ovary contained white visible follicles or soft yellow ones, the oviducal glands were enlarged and developed and the uteri were expanding from posterior to anterior. Mature animals were those in which the ovary was fully developed with strong big and yellow follicles accompanying others smaller and also yolked. The epigonal organ observed associated with the ovary was highly reduced in this stage of maturation. The oviducal glands were fully developed and with sperm storage in them. The uteri were completely expanded or contained embryos. Of these mature animals, 5 were pregnant with in utero embryos. Each animal was humanely terminated by blunt trauma to the cranium. A longitudinal ventral incision was made in each animal so as to remove the oviducal glands then, the pieces were stored in Bouin solution for light microscopy and in $2.5 \%$ glutaraldehyde in $0.1 \mathrm{M}$ cacodylate with $12 \%$ saccarose for transmission and scanning microscopy.

Light microscopy. Samples from the oviducal glands were dissected, stored in Bouin overnight and then dehydrated through a series of progressively higher alcohol concentrations (70$100 \%)$. After that, were infiltrated in paraffin and made blocks with them.

Sections of $5 \mu \mathrm{m}$ thick were cut with a sliding microtome then affixed to glass slides. Separate sections were stained with Haematoxylin and Eosin, combined Alcian Blue and Periodic Acid-Schiff and Masson's trichrome Stain. After that, sections were mounted with Canada balsam mounting media and covered with glass microscope coverlips. Sections were photographed by a camera C7070 Olympus adapted to an Olympus BX51 light microscope.

The oviducal gland slide was scanned using a Scanner HP Scanjet 5590 L1910A and edited with Adobe Photoshop CS6.
Transmission electron microscopy. Tissue samples were first fixed in $2.5 \%$ glutaraldehyde in $0.5 \mathrm{M}$ cacodylate buffer (pH 7.4) with $12 \%$ of sucrose (Hyder et al. 1983) at $4^{\circ} \mathrm{C}$, for 12 hours. The samples were subsequently washed three times with the buffer for $30 \mathrm{~min}$ each at $4^{\circ} \mathrm{C}$ and then postfixed in osmium tetroxide in the same buffer, for 1 hour at $4^{\circ} \mathrm{C}$. They were dehydrated in graded ethanol $(50 \%, 70 \%, 80 \%, 95 \%$ and three times in $100 \%$ ethanol) and infiltrated in low density resin (Spurr). The blocks of tissue were at first, sectioned at 1 $\mu \mathrm{m}$ thick (semithin sections) with a Super Nova Reichert-Jung Ultra-microtome at a $90 \mathrm{~nm}$ width with a glass knife and stained in drops of $2 \%$ uranyl acetate, followed by lead citrate for $30 \mathrm{~min}$. Ultrathin sections were made at $60 \mathrm{~nm}$. Finally, each of the sections was examined and photographed $(20$ images each with an ES1000W Erlangshen CCD Camera, Model 785, (Gatan Inc., Pleasanton, California, USA) using a JEM 1200 EX II transmission electron microscope (JEOL Ltd., Tokio, Japan) at $80 \mathrm{kV}$, belonging to the Servicio Central de Microscopía Electrónica de la Facultad de Ciencias Veterinarias, Universidad Nacional de La Plata (Argentina).

Scanning electron microscopy. Tissue samples from the oviducal gland were fixed in $2.5 \%$ glutaraldehyde in $0.5 \mathrm{M}$ cacodylate buffer $(\mathrm{pH} 7.4)$ with $12 \%$ of sucrose at $4^{\circ} \mathrm{C}$. After the fixation, samples were washed 3 times with bidistilled water during 10 minutes each. Then, they were dehydrated through progressively higher acetone concentrations: 1 wash with acetone $25 \%$ (10 minutes), 1 wash with $50 \%$ and a third wash with acetone $80 \%$. Finally, the samples were dried by critical point method (Cohen, 1974) and impregnated with gold before examination at a magnification of 350-7500X with the Scanning Electron Microscope (SEM) (JEOL JSM 6360 LV).

\section{RESULTS}

Macroscopically the oviducal gland can be observed in Figure 1 with its heart-shape. Immature OG was an expansion of the oviduct. At the beginning of maturation the lumen expanded and in a posterior phase, the surface of the epithelium folds gave the characteristic shapes of each zone (Fig.2, 3).

The mature oviducal gland was formed by four morphological zones: the club, papillary, baffle and terminal zones. Basically, each zone consisted of secretory tubules supported by vascularized connective tissue which released their secretions into the lumen (Fig.4 and 5).

\section{Club zone}

The club zone was characterized by folds axe-shaped. These folds alternated with depressions into which simple tubular glands empty (Fig.6). The epithelium of the tubules presented two types of cells: one, with apical nuclei with chromatine granules and ciliated and the other type, located basally in the tubule, was represented by secretory cells with round basal nuclei with chromatine granules, stained PAS (+) and AB (+).

\section{Papillary zone}

The papillary zone was distinguished by elongated lamellae with cells containing oval euchromatic nuclei that alternated with simple tubular glands that were PAS (+) and $\mathrm{AB}(-)$ (Fig.7, 8).The epithelium was simple columnar ciliated like the club zone. These glands stained more 

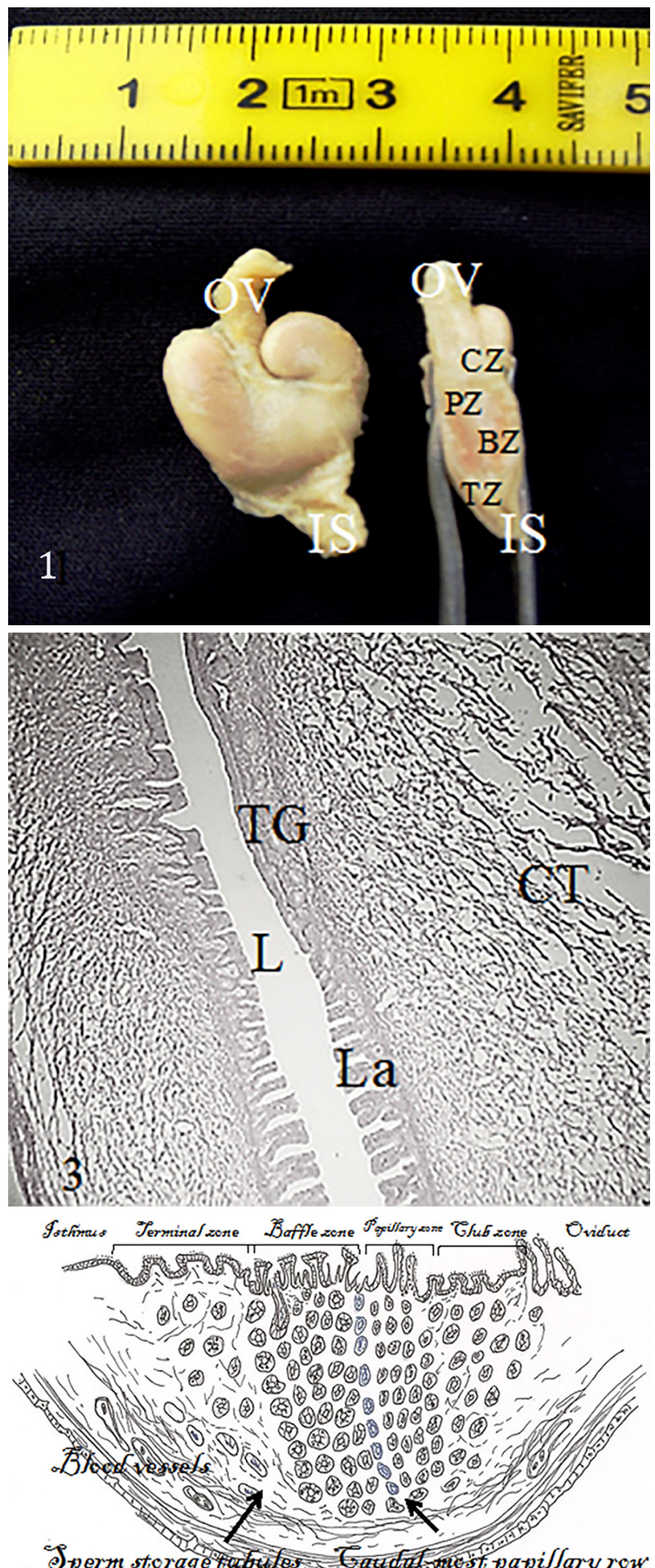

5

intensely PAS (+) than the club zone tubules. Only three or four folds were developed along this zone. These lamellae were less numerous than those in the others zones (Fig.8).

The caudal-most papillary lamella consisted of a single row of tubules AB (+) (Fig.9). These tubules' epithelium presented two types of cells that were characterized by basal heterochromatic nuclei and luminal nuclei with euchromatic components (Fig.10).
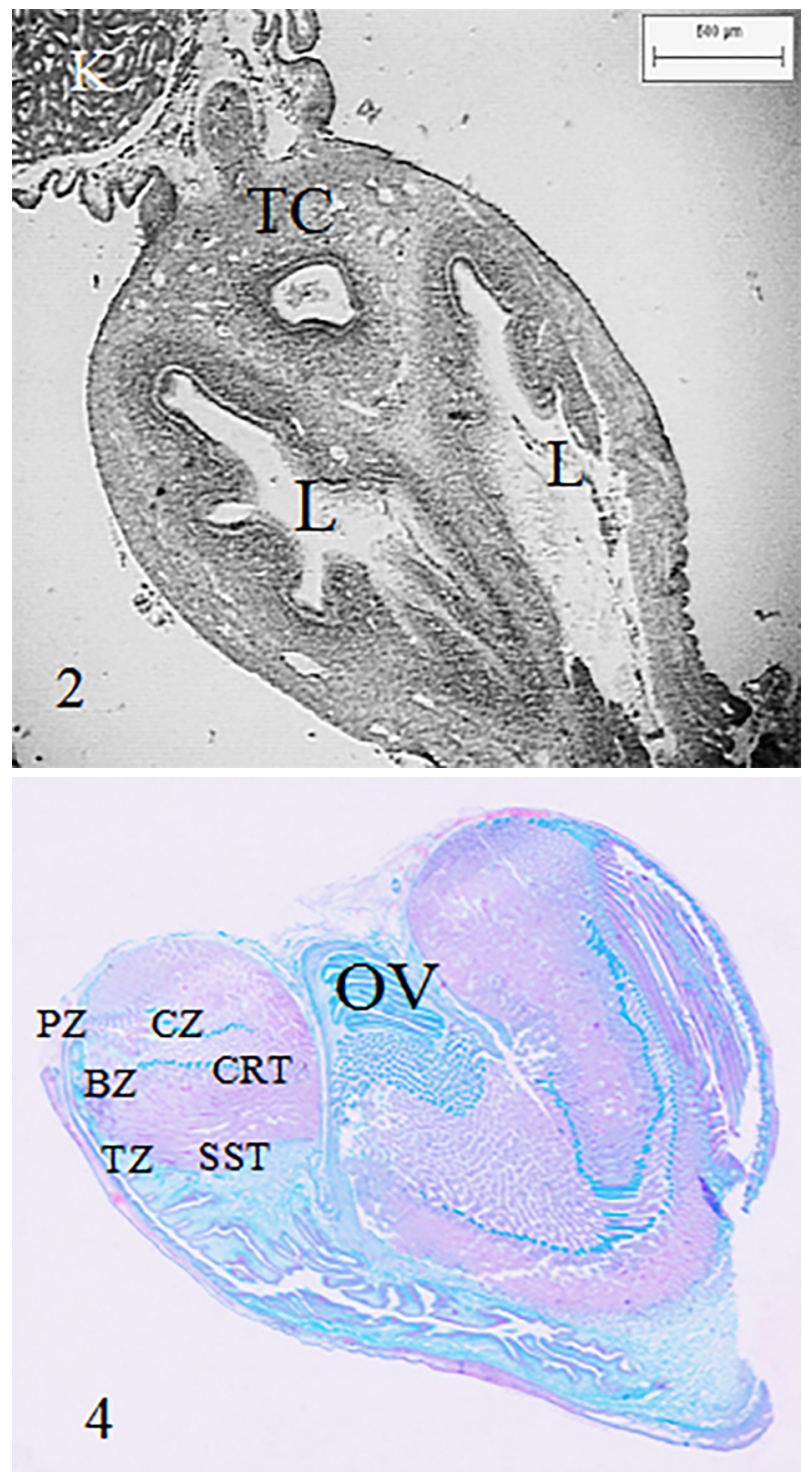

Fig.1. Gross anatomy of the mature oviducal gland.

Fig.3. Sagital section of an immature oviducal gland in a more developed stage than Figure 2. The lamellae are folding and the tubules are appearing. PAS. 10x. BZ = Baffle zone, $\mathrm{CT}=$ Connective tissue, $\mathrm{CZ}=$ Club zone, $\mathrm{IS}=$ Isthmus, $\mathrm{K}=$ Kidney, $\mathrm{L}$ =Lumen, La = Lamella, PZ = Papillary zone, OV = Oviduct, $\mathrm{TG}=$ Tubular glands, $\mathrm{TZ}=$ Terminal zone.

Fig.2. Sagittal section of an immature oviducal gland. Masson.

Fig.4. Sagital section of the mature oviducal gland showing histological staining of the different zones. PAS/AB. 9600ppp.

Fig.5. Schematic drawing of the organization of the zones in the oviducal gland.

\section{Baffle zone}

The baffle zone showed a functional unit formed by a plateau projection with a connective tissue core alternating with spinnerets, which were small projections disposed along both sides of the plateau. This whole structure was present in number of 8 or 9 units. A simple columnar ciliated epithelium covered the plateau and spinnerets and no $\mathrm{AB}$ or PAS staining was observed. There were two types of cells forming the tubules, one was ciliated with apical oval 

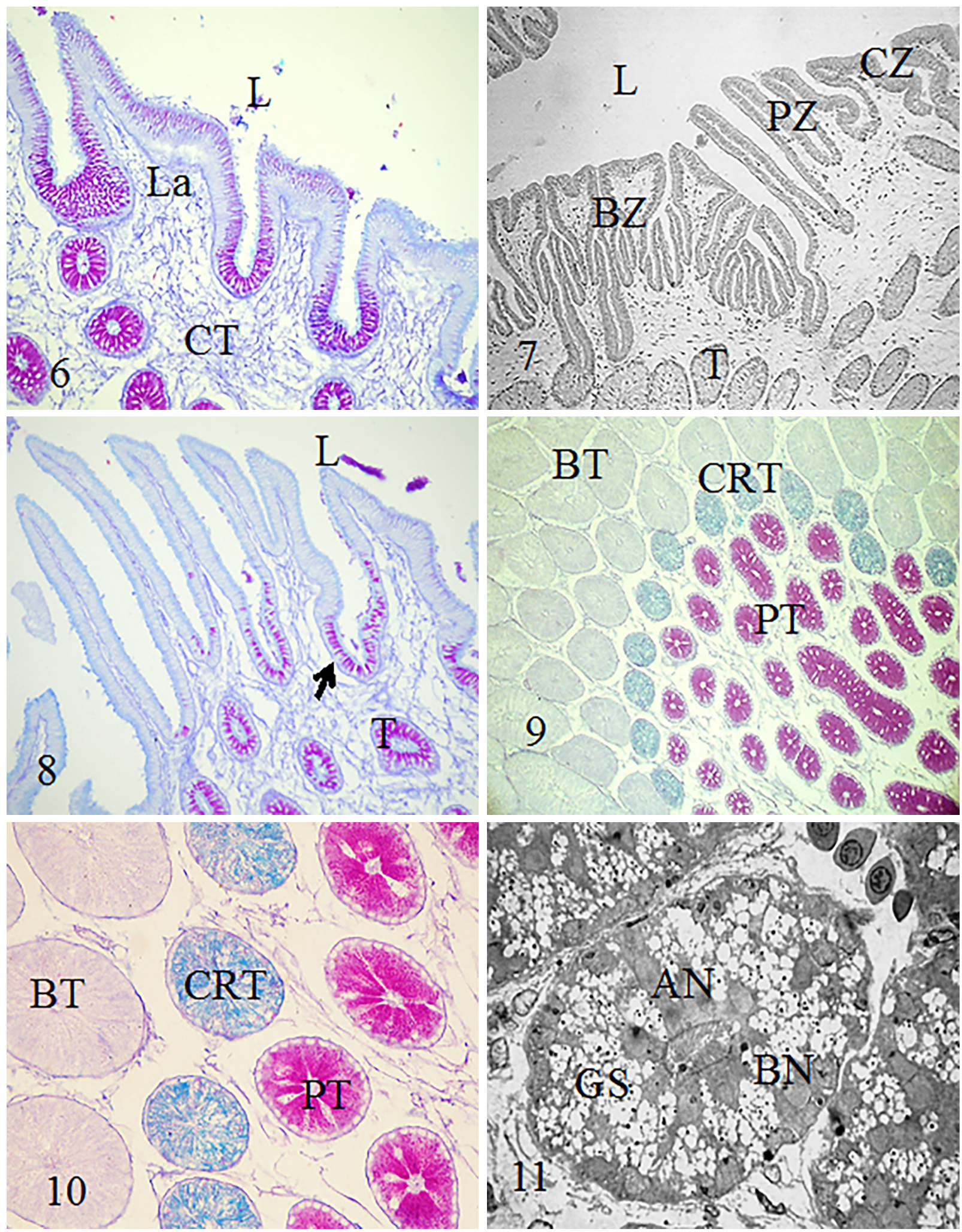

Fig.6. The structure of the club zone. Secretory cells between the lamellae stained positively PAS/AB. PAS/AB, 20x.

Fig.8. Papillary zone secretory cells with basal nuclei and PAS granules(arrow). PAS/AB.20x. BZ = Baffle zone, $\mathrm{CZ}=\mathrm{Club}$ zone, $\mathrm{CT}=$ Connective tissue, $\mathrm{L}=$ Lumen, $\mathrm{La}=$ Lamellae, $\mathrm{PZ}=$ Papillary zone, $\mathrm{T}=$ Tubules.

Fig.10. A more detailed section of the tubules between baffle and papillary zones. $\mathrm{PAS} / \mathrm{AB}, 40 \mathrm{x}$.

Fig.7. The structure of the club, papillary and baffle zones. Masson, 20x.

Fig.9. The caudal-most papillary row of tubules stained $\mathrm{AB}(+)$ while the rest of the papillary's zone tubules stained strongly PAS(+). PAS/AB, 10x.

Fig.11. Semithin section of the baffle zone tubule. The ciliated cells with apical nuclei are less numerous than secretory cells with basal nuclei. Toluidine, 100x. 

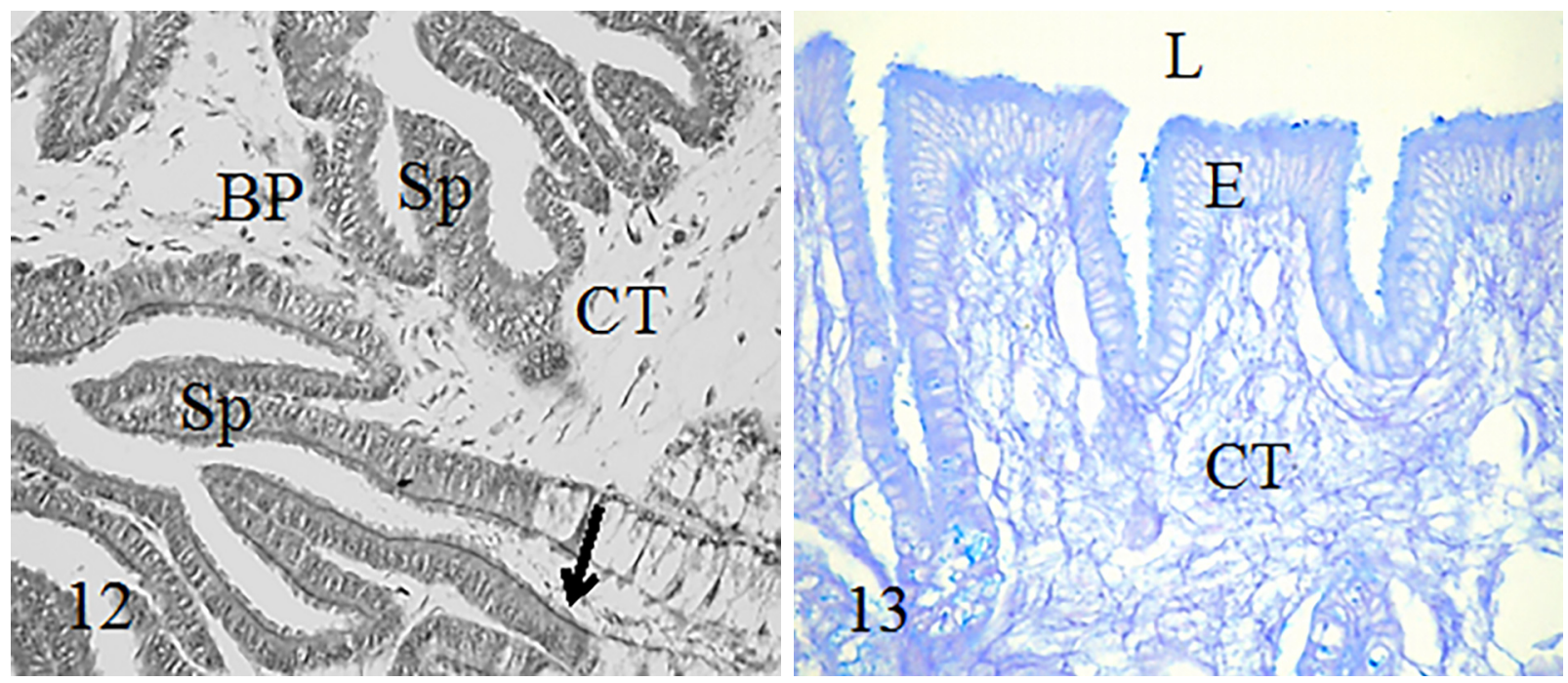

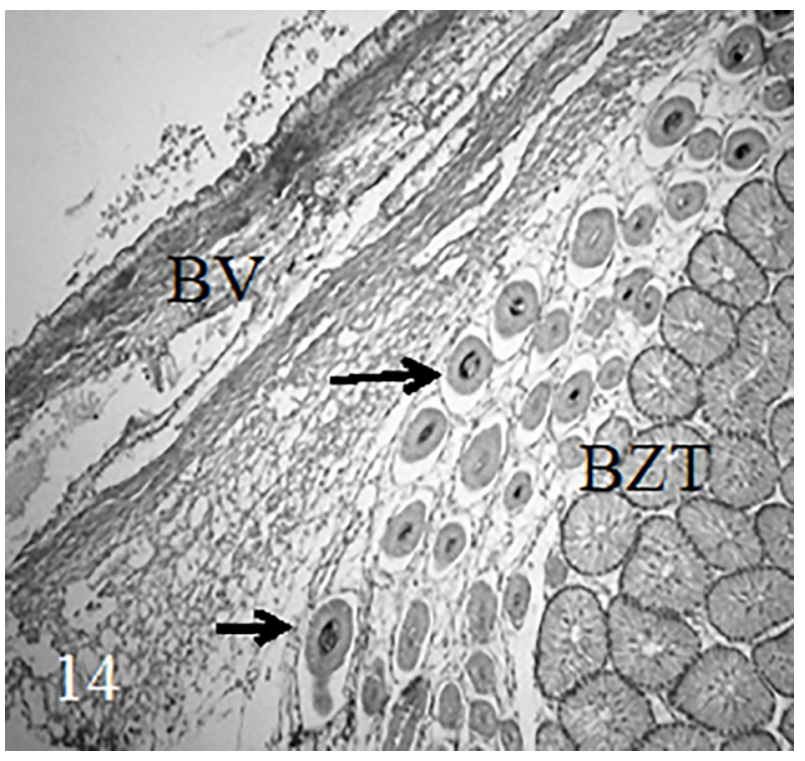

Fig.12. Sperm in the baffle zone (arrow). Masson. 40x. AN = Apical Nuclei. $\mathrm{BC}=$ Blood cells, $\mathrm{BN}=$ Basal nuclei, $\mathrm{BP}=$ Baffle plate, $\mathrm{BT}=$ Baffle tubules, $\mathrm{BV}=$ Blood vessel CRT $=$ Caudal-most row of tubules, $\mathrm{CT}=$ Connective tissue, $\mathrm{PT}=$ Papillary tubules, $\mathrm{Sp}$ $=$ Spinneret.

Fig.14. Sperm storage in the terminal zone (arrows). The sperm storage tubules are positioned near to the Baffle zone and are associated with blood vessels. Masson, 10x.

nuclei and the other was secretory with basal rounded nuclei. The ciliated cells were less numerous than the secretory ones. Electron microscopy showed secretory cells with light staining vesicles with a dense core in some of them (Fig.11).

It was also detected sperm in the surface of the baffle zone (Fig.12). It was assumed that it was on its way to fertilize the ovum.

\section{Terminal zone}

The epithelium of this zone contained ciliated cells with apical nuclei and secretory cells with basal nuclei that stain AB (+) (Fig.13). The terminal zone was formed by elongated tubules that ran adjacent to the baffle zone where groups of spermatozoa were clearly observed in the lumen

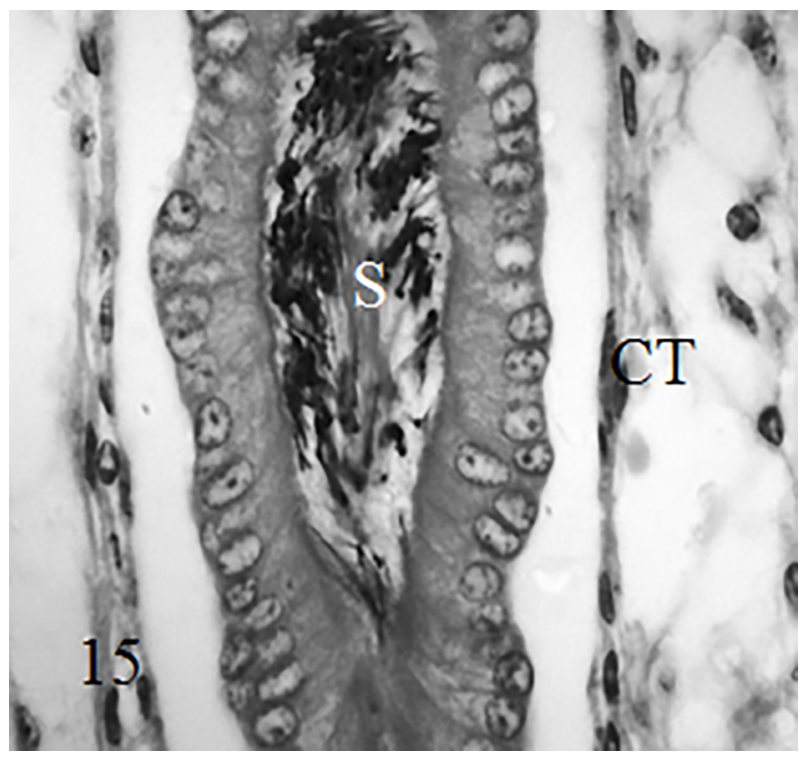

Fig.13. Epithelium of the Terminal zone with $\mathrm{AB}(+)$ secretory cells. PAS/AB, 40x.

Fig.15. A detail of a sperm storage tubule in the Terminal zone. Masson, 100x.

(Fig.14) indicating the sperm storage place. These tubules were associated with blood vessels. The bundles of spermatozoa presented no pattern in their disposition (Fig.15). The epithelium of the sperm storage tubules did not stain with any of the dyes tested.

It was also observed sperm in club's (Fig.16) and baffle's zones (Fig.17) in Mustelus schmitti in a pregnant female.

Semi thin sections revealed differences between the terminal zone tubules that storaged sperm and those which did not. Terminal zone tubules with no sperm, had secretory cells with basal nuclei and round secretory granules (Fig.18). Using TEM, appeared clearly the apical nuclei of the ciliated cells and the round granules of secretion that displaced the nuclei to a basal position (Fig.19).

Sperm storage was observed in the oviducal gland along the reproductive cycle, even when the female was pregnant. This would show that the female tract could retain 


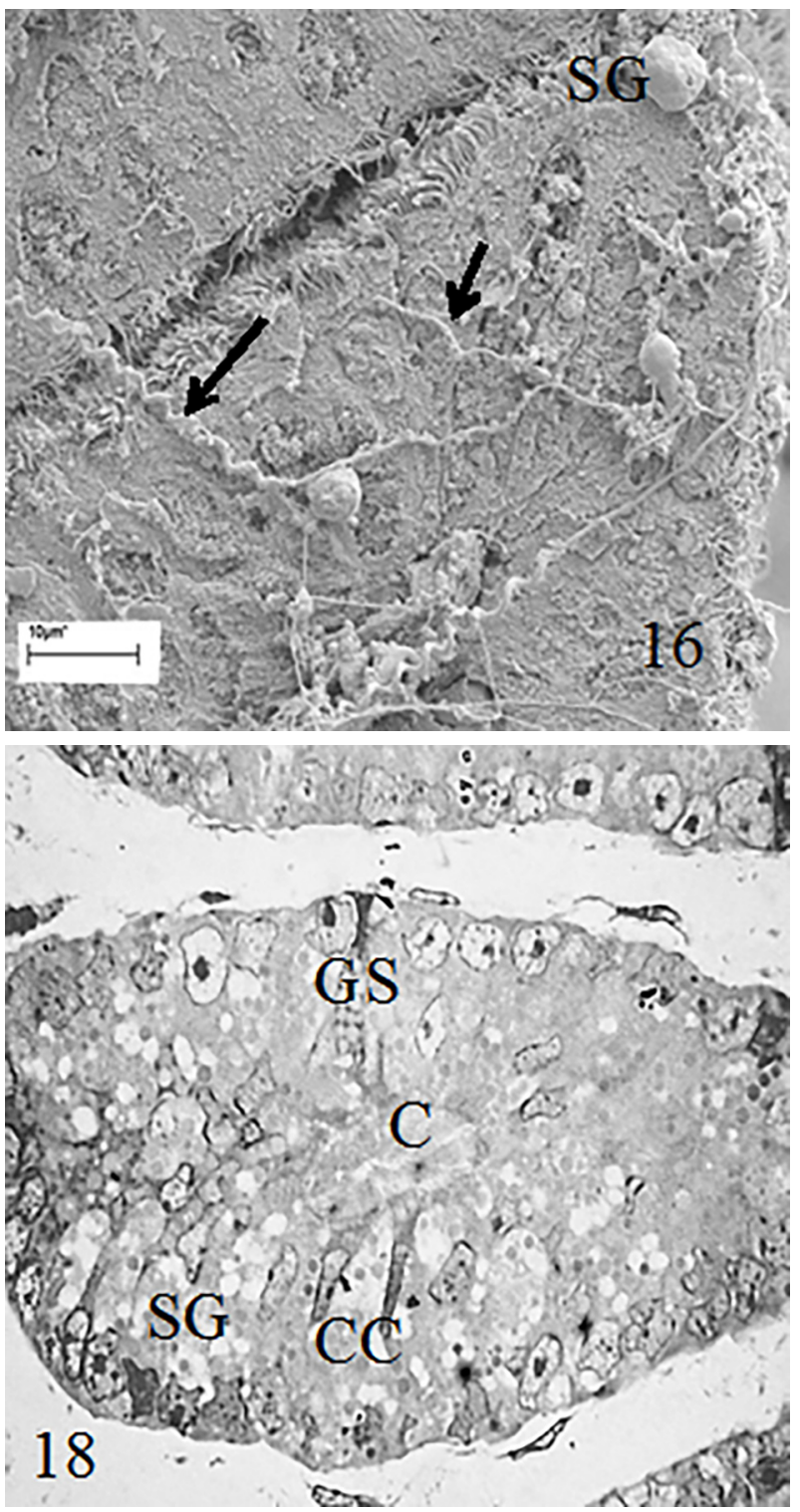

Fig.16. Scanning electron micrograph of the presence of spermatozoa (arrows) in the Club zone. BV = Blood vessel, BZT $=$ Baffle zone tubules, $\mathrm{CT}=$ Connective tissue, $\mathrm{E}=$ Epithelium, $\mathrm{L}=$ Lumen, $\mathrm{S}=$ Sperm, $\mathrm{SG}=$ Secretory granules.

Fig.18. Semithin section of the Terminal zone tubule. The granules of secretion are completely round and different from those of the Baffle tubules. Toluidine, 100x.

the spermatozoa in the oviducal gland for about 11 months. A noteworthy observation was that the secretion in the sperm storage tubules was scarce and was not in contact with the sperm (Fig.20). Transmission electron microscopy confirmed this in detail (Fig.21).

\section{DISCUSSION}

This particular gland functions to produce egg jelly, forms the tertiary egg envelope, stores sperm, protects sperm from immunological attack by the mother and nourishes sperm (Hamlett et al. 2005). This gland allows the formation of the jelly coats being pliable which constitutes a strategy to form quite big egg-coverings in a reduced space.
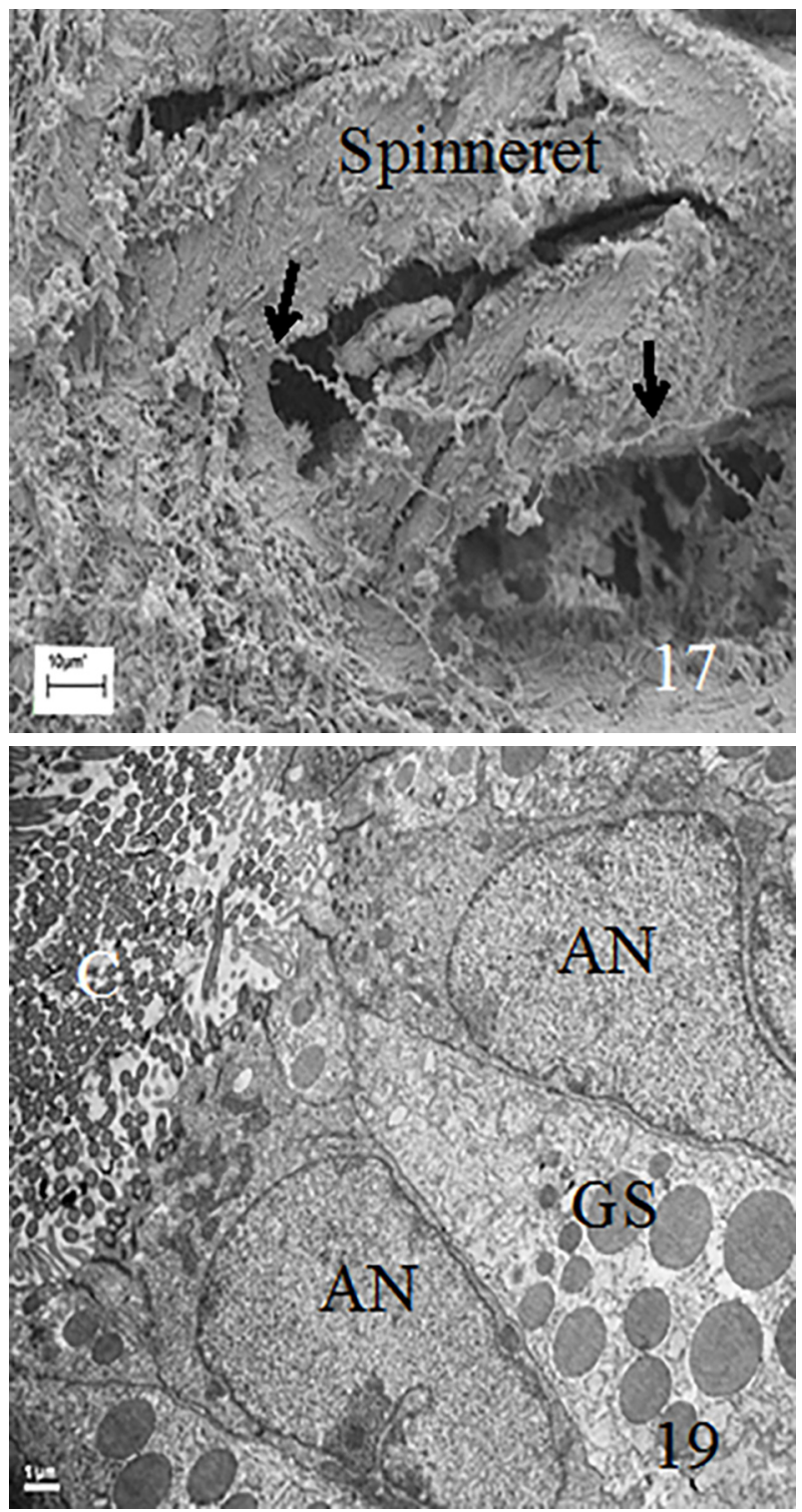

Fig.17. Scanning electron micrograph of the presence of the spermatozoa (arrows) in the Baffle zone.

Fig.19. TEM of a Terminal zone tubule. Clearly is showed the apical nuclei of the ciliated cells and the round granules of secretion that displaced the nuclei to a basal position. Toluidine, 100x.

Almost all chondrichthyan species present the characteristic four zones in their oviducal glands: club, papillary, baffle and terminal. The club and papillary zones are present in oviparous or viviparous species and are responsible for producing the jelly coats that envelops the egg. Even in Urobatis jamaicensis which has no baffle zone because it does not produce an egg envelope, both zones, club and papillary, appear (Hamlett et al. 1998, Hamlett et al. 1999).

The baffle zone produces the various types of egg coats that are common in Chondrichthyan fishes (Hamlett et al. 1998). The terminal zone is responsible for storing sperm in its tubules and produces the secretions to form the hair filaments on the surface of the capsule in some species of Raja (Hamlett et al. 2002). 


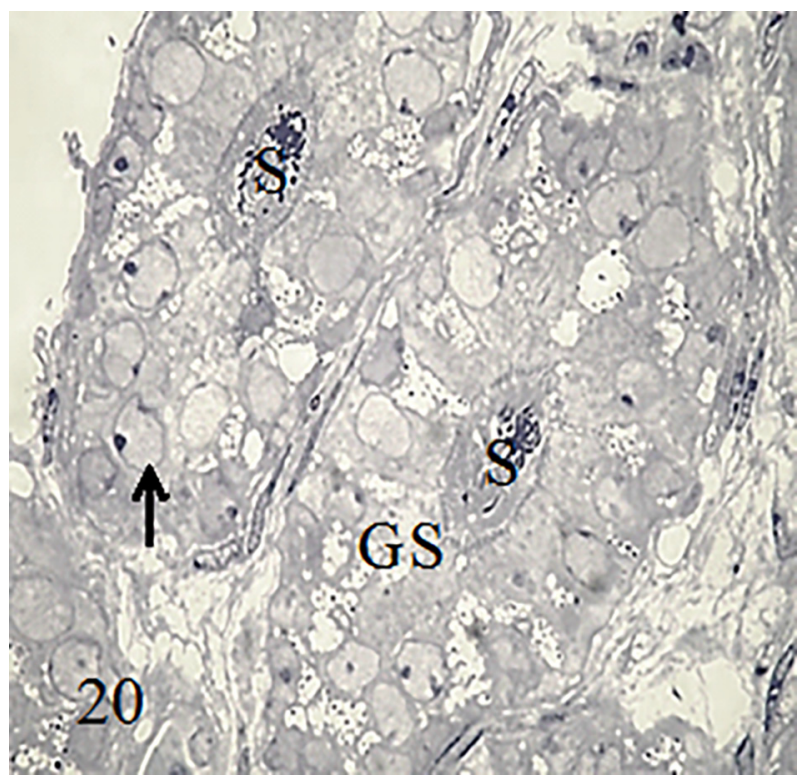

Fig.20. Semithin section of sperm storage tubules. There are scarce granules of secretion and they are not in touch with sperm. Euchromatic basal nuclei present 1 or 2 nucleoli (arrow).

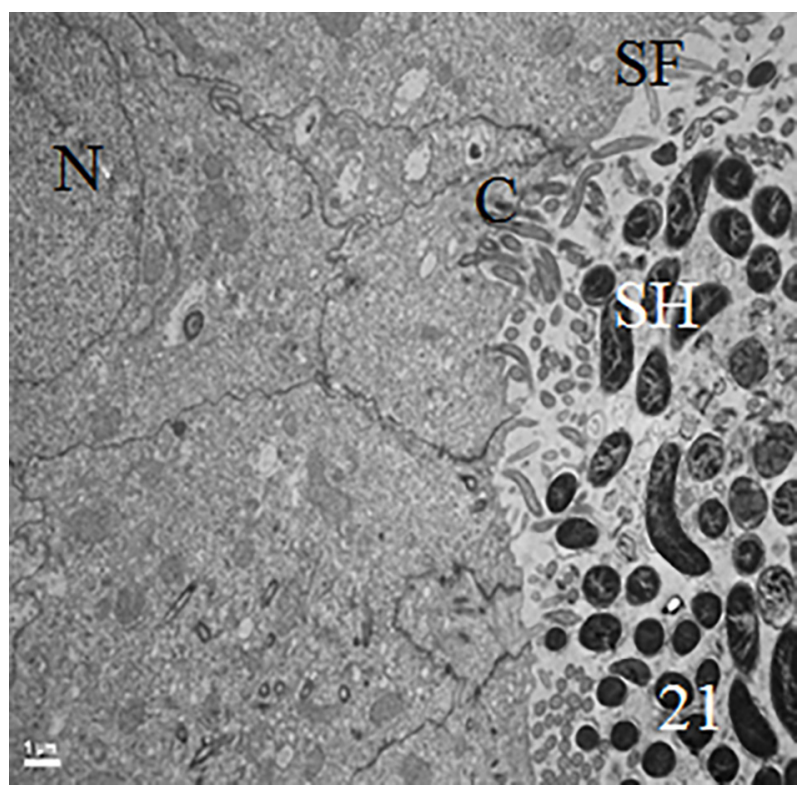

Fig.21. TEM of sperm in Terminal zone tubule. AN = apical nuclei, $\mathrm{C}=$ cilia, $\mathrm{CC}=$ Ciliated cells, $\mathrm{SC}=$ Secretory cells, $\mathrm{SH}=$ Sperm head, GS = Granules of secretion, $\mathrm{N}=$ Nucleus, $\mathrm{S}=$ Sperm, SF Sperm flagellum.

Diversity in the nature of the jelly investment may also exist in species with different reproductive modes. In some sharks and rays, the egg and jelly fill the entire envelope; the developing embryos break out of the envelope to complete their development free in the uterus. In other viviparous species the jelly occupies only a small proportion of the envelope. In placental sharks the modest jelly component surrounds the fertilized egg during the early stages of gestation (Hamlett et al. 2002a).

PAS technique is used to recognize glycoproteins or any mucous substance containing neutral sugars. $\mathrm{AB}$ pH 2.5 indicates sulfated, non-sulfated acid glycosaminoglycans and sialoglycoproteins. Therefore glycoproteins or any mucous substance containing neutral sugar are found in the cells of the base of the club zone lamellae and in the tubules that form the club and papillary zones. On the other hand, sulfated, nonsulfated acids glycosaminoglycans and sialoglyproteins are secreted by club and terminal cells of the tubules. The exact chemical composition of the secretions has yet to be determined.

Considering the histochemical studies of the oviducal gland of Callorhynchus milli (Smith et al. 2004) it is possible

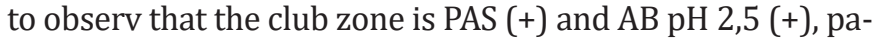
pillary zone is $\mathrm{AB}(+)$, baffle zone is $\mathrm{PAS}$ and $\mathrm{AB}(-)$ and terminal zone is strongly $\mathrm{AB}(+)$. Comparing with Mustelus schmitti we found that the club, baffle and terminal zones are identical histochemically while the papillary zone is PAS (+), AB (-).

The Oman shark, Iago omanensis presents the four typical zones in their oviducal glands and the cells that form this organ are practically identical (Fishelson \& Baranes 1998, Hamlett et al. 2002a) to those Mustelus schmitti shows but in the latter, the terminal zone is $\mathrm{AB}(+)$ and PAS $(-)$. Terminal zone in Oman's shark is PAS (+).There are differences between the papillary and terminal zones of the Callorhynchus milli and Iago omanensis respectively with those that belong to Mustelus schmitti. The three species have developed different modes of reproduction so that would be the reason for the different secretions. Anyway, further investigation is needed to elucidate this question.

Sperm was found in the baffle zone of Mustelus schmitti's oviducal gland but it is because they are on the way to the anterior oviduct where fertilization takes place. This sperm may be removed away when the fertilized eggs come down to the uterus. Only the terminal zone is the area up to date, considered where sperm is in storage. Others authors also mentioned the presence of sperm in the baffle zone (Stevens 2002, Basallo et al. 2011) but inside the tubules, suggesting this site like another sperm storage place.

Baffle zone complexity is directly related with the complexity of the capsule produced, but as Mustelus schmitti is a viviparous aplacental species this zone has a simple structure and so the club and papillary zones are not too developed.

The presence of sperm in the club zone of a pregnant female would indicate the sperm storage fertilizes eggs instead of fresh sperm. Chiaramonte \& Pettovello (2000) suggest that mating occurs before parturition with immediate ovulation and they caught a female with embryos and eggs "in utero" and small oocytes in the ovary and, another one with embryos and uterine eggs. Some scarce examples of females with embryos and eggs have been reported by fishermen. A possible explanation to this question could be that fertilization occurs by storage sperm and sometimes could descend ova before parturition takes place. Ovulation would occur simultaneously with pregnancy. Matings couldn't happen before parturition because the pass of the embryo through the cervix would drag along the sperm from the uterus.

Maruska et al. (1996) found sperm in oviducal gland of Dasyatis sabina without specifying the zone.

Noteworthy is that the epithelium that keeps sperm is $\mathrm{AB}$ and PAS (-). Also is remarkable that the baffle epithelium where bundles of spermatozoa had been found, gives the same reaction as the terminal zone epithelium. Studies 
like these have been performed in a teleost fish, Helicolenus dactylopterus dactylopterus, where the ovaric epithelium releases PAS strongly positive granules to the place where spermatozoa is kept in the first stages of the storage period (Muñoz et al. 2002). Maybe the sperm in Mustelus schmitti need a neutral environment so as not to enter in the capacitation reaction.

Pratt (1993) studied eleven species of sharks that belong to the North Atlantic east coast and found sperm storage in nine of them (Alopias vulpinus, Lamna nasus, Carcharinus obscurus, Carcharinus plumbeus, Galeocerdo cuvieri, Prionacea glauca, Rhizoprionodon terranovae, Sphyrna lewini and Sphyrna tiburo). Only Isurus oxyrinchus, Alopias superciliosus lack of sperm in their respective oviducal glands. Meanwhile only one adult female of Alopias vulpinus had a moderate amount of spermatozoa in tubules and lumen of the oviducal gland. This author considered that Lamniform sharks being plesiomorphic developed a simpler insemination styles. Instead, Carchariniform sharks display much more variety of modes of reproduction.

Hamlett et al. (1998) made a survey of various oviducal glands of different species like Scyliorhinus canicula, S. stellaris, Raja erinacea, $R$. eglanteria, $R$. clavata, Squalus acanthias, Mustelus canis and Urobatis jamaicensis and the morphology of this organs display the same four zones regardless the mode of reproduction of each species.

Terminal zone is the last zone of the oviducal gland, which is the site of formation the hairs that adorn the external capsule in oviparous species. As Mustelus schmitti is viviparous, this zone only stores sperm and depicts low folds that descend into the uterus. On the contrary, Serra-Pereira et al. (2011) investigated Raja clavata and found the terminal zone is not involved in sperm storage and is much extended in its surface due to the formation of the surface hairs of the egg capsule.

\section{REFERENCES}

Babel J.S. 1967. Reproduction, life history and ecology of the round stingray, Urolophus halleri Cooper. Calif. Fish Game Bull. 137:1-104.

Basallo A., Varela Junior A.S. \& Oddone M.C. 2011. Armazenamento de esperma da glândula ovidutal da raia ovípara Atlantoraja platana (Günther, 1880) (Chondrichthyes, Rajoidei). XIV Congreso Latino-americano de Ciencias do Mar (COLACMAR), Camboriú, Brasil. (Abstract)

Chiaramonte G.E. \& Pettovello A.D. 2000. The biology of Mustelus schmitti in southern Patagonia, Argentina. J. Fish Biol. 57:930-942.

Conrath C.L. \& Musick J.A. 2002. Reproductive biology of the smooth dogfish, Mustelus canis, in the northwest Atlantic Ocean. Environ. Biol. Fishes 64:367-377.

Fishelson L. \& Baranes A. 1998. Observations on the Oman shark, Iago omanensis (Triakidae), with emphasis on the morphological and cytological changes of the oviduct and yolk sac during gestation. J. Morphol. 236:151-165.

Hamlett W.C. 1996. Ultrastructure of the oviducal gland in the yellow spotted stingray, Urolophus jamaicensis, with observations on a novel inclusion. J. Anatom. 188:244-245.

Hamlett W.C., Knight D.P., Koob T.J., Jezior M., Luong T., Rozycki T., Brunette N. \& Hysell M.K. 1998. Survey of oviducal gland structure and function in elasmobranchs. J. Exp. Zool. 282:399-420.

Hamlett W.C. \& Hysell M.K. 1998a. Uterine specializations in Elasmobranchs. J. Exp. Zool. 282:438-459.
Hamlett W.C. 1999. Male reproductive system, p.444-470. In: Hamlett W.C. (Eds), Sharks, Skates \& Rays: The Biology of Elasmobranch Fishes. The John Hopkins University Press, Baltimore.

Hamlett W.C., Musick J.A., Hysell C.K. \& Sever D.M. 2002. Uterine epithelial-sperm interaction, endometrial cycle and sperm storage in the terminal zone of the oviducal gland in the placental Smoothhound, Mustelus canis. J. Exp. Zool. 292:129-144.

Hamlett W.C., Fishelson L., Baranes A., Hysell C.K. \& Sever D.M. 2002a. Ultrastructural analysis of sperm storage and morphology of the oviducal gland in the Oman shark, Iago omanensis (Triakidae). Marine Freshwater Research 53:601-613.

Hamlett W.C., Knight D.P., Pereira F.T.V., Steele J. \& Sever D.M. 2005. Oviducal glands in chondrichthyans, p.301-335. In: Hamlett W.C. (Ed.), Reproductive Biology and Phylogeny of Chondrichthyes: Sharks, Batoids and Chimaeras. Science Publ., USA.

Hyder S.L., Cayer M.L. \& Pettey C.L. 1983. Cell types in peripheral blood of the nurse shark: an approach to structure and function. Tissue and Cell 15:437-55.

Knight D.P., Feng D. \& Stewart M. 1996. Structure and function of the Selachian egg case. Biol. Rev. 71:81-111.

Knupp C., Chew M., Morris E. \& Squire J. 1996. Three-dimensional reconstruction of a collagen IV analogue in the dogfish egg case wall. J. Struct. Biol. 117:209-221.

Knupp C., Chew M. \& Squire J. 1998. Collagen packing in the dogfish egg case wall. J. Struct. Biol. 122:101-110.

Knupp C. \& Squire J. 1998. X-ray diffraction analysis of the 3D organization of collagen fibrils in the wall of the dogfish egg case. Proc. R. Soc. B 265:2177-2186.

Koob T.J. \& Cox D.L. 1988. Egg capsule catechol oxidase from the little skate Raja erinacea Mitchill, 1825. Biol. Bull. 175:202-211.

Maruska K., Cowie E.G. \& Tricas T.C. 1996. Periodic gonadal activity and protracted mating in elasmobranch fishes. J. Exp. Zool. 276:219-232.

Metten H. 1939. Studies on the reproduction of the dogfish. Phil. Trans. R. Soc. B 230:217-238.

Muñoz M., Koya Y. \& Casadevall M. 2002. Histochemical analysis of sperm storage in Helicolenus dactylopterus dactylopterus (Teleostei: Scorpaenidae). J. Exp. Zool. 292:156-164.

Nalini K.P. 1940. Structure and function of the nidamental gland of Chiloscyllium griseum (Müller et Henle). Proc. Indian Acad. Sci. B. 12:189-214.

Oddone M.C., Mesa A. \& Ferreira de Amorim A. 2008. Description of the egg capsule of Atlantoraja castelnaui (Elasmobranchii, Rajidae). Braz. J. Oceanogr. 56:65-68.

Prasad R.R. 1945. The structure, phylogenetic significance and function of the nidamental glands of some elasmobranchs of the Madras Coast. Proc. Natl Inst. Sci. India 11:282-302.

Prasad R.R. 1951. Observations on the Egg cases of Some Ovoviviparous and Viviparous Elasmobranchs, with a Note on the Formation of the Elasmobranch Egg case. Jour Bombay Nat Hist Soc. 49:755-763

Pratt H.L. 1993. The storage of spermatozoa in the oviducal glands of western North Atlantic sharks. Environ. Biol. Fishes 38:139-149.

Rusaoüen M., Pujol P.J., Bocquet J., Veillard A. \& Borel J.P. 1976. Evidence of collagen in the egg capsule of the dogfish Scyliorhinus canicula. Comp. Biochem. Physiol. B 53:539-543.

Serra-Pereira B., Alfonso F., Farias I., Joyce P., Ellis M., Figueiredo I. \& Serrano Gordo L. 2011. The development of the oviducal gland in the rajid thornback ray, Raja clavata. Helgoland Mar. Res. 65:399-411.

Smith R.M., Walker T.I. \& Hamlett W.C. 2004. Microscopic organization of the oviducal gland of the holocephalan elephant fish, Callorhynchus milli. Mar. Freshwater Res. 55:155-164.

Stevens B. 2002. Uterine and Oviducal Mechanisms for Gestation in the Common Sawshark, Pristiophorus cirratus. Thesis of Bachelor of Science, Department of Zoology, University of Melbourne, Australia. 43p.

Storrie M.T., Walker T.I., Laurenson L.J. \& Hamlett W.C. 2008. Microscopic organization of the sperm storage tubules in the oviducal gland of the female gummy shark (Mustelus antarticus), with observations on sperm distribution and storage. J. Morphol. 269:1308-1324. 